\title{
ARMENIAN EXPEDITION OF EMPEROR CONSTANTIUS II IN 338/339 A.D. AND MILITARY UNITS OF THRACIAN EXPEDITIONARY ARMY AT THE NEAR EAST: ON THE LATE ROMAN MILITARY ORGANIZATION IN THE MID-4 ${ }^{\mathrm{TH}}$ CENTURY
}

\author{
Evgeniy A. Mekhamadiev \\ Saint Petersburg State University, Saint-Petersburg, Russian Federation
}

\begin{abstract}
The present paper deals with the history of military corps, which Roman emperor Constantius II sent to Great Armenia in 338/339 A.D. for to fight with the Persians. The main evidence on Constantius II's Persian expedition are preserved in the works of prominent Armenian historians, that are Moses Khorenatsi and Pawstos Buzand. Constantius II held this campaign in order to free Armenia from the Persians and to bring back its state freedom. According to Moses Khorenatsi and Pawstos Buzand, Constantius II sent in Armenia bodyguards, who were representatives of Armenian noble families allied to the Romans, but the Roman regular forces themselves collected in Galatia (the Asia Minor), moved in Mesopotamia and Atropatene (south of modern Azerbaijan and Iranian Azerbaijan). As the author supposes, Roman troops arrived in Armenia and took part in fight with the Persians, strictly due to Roman military help Armenian naxarars could expel the Persians from Armenia. In this connection the author poses a question - which military units arrived at the Roman Near East (in Mesopotamia) from the Asia Minor and how Constantius II's military campaign in Armenia influenced on the further development of Roman-Persian frontier and its defence system. On the ground of epigraphic data (inscriptions from Mesopotamia and Arabia) author made a conclusion that in 338/339 A.D. Constantius II moved at the Near East military units which previously were parts of Thracian expeditionary army and garrisoned in Thracia, since inscriptions under discussion mention soldiers who bear Thracian names that reveal their Thracian origin.
\end{abstract}

Key words: Constantius II, Thracia, expeditionary army, inscriptions, the Near East, Great Armenia.

Citation. Mekhamadiev E.A. Armenian Expedition of Emperor Constantius II in 338/339 A.D. and Military Units of Thracian Expeditionary Army at the Near East: on the Late Roman Military Organization in the Mid- $4^{\text {th }}$ Century. Vestnik Volgogradskogo gosudarstvennogo universiteta. Seriya 4, Istoriya. Regionovedenie. Mezhdunarodnye otnosheniya [Science Journal of Volgograd State University. History. Area Studies. International Relations], 2017, vol. 22, no. 5, pp. $288-299$ (in Russian). DOI: https://doi.org/10.15688/jvolsu4.2017.5.26

\section{АРМЯНСКАЯ ЭКСПЕДИЦИЯ ИМПЕРАТОРА КОНСТАНЦИЯ ІІ В 338/339 ГОДАХ И ВОЙСКОВЫЕ ПОДРАЗДЕЛЕНИЯ ЭКСПЕДИЦИОННОЙ АРМИИ ФРАКИИ НА БЛИЖНЕМ ВОСТОКЕ: К ВОПРОСУ О ПОЗДНЕРИМСКОЙ ВОЕННОЙ ОРГАНИЗАЦИИ В СЕРЕДИНЕ IV ВЕКА}

\section{Евгений Александрович Мехамадиев}

Санкт-Петербургский государственный университет, г. Санкт-Петербург, Российская Федерация

Аннотация. Статья рассматривает историю войсковой группировки, которую римский император Констанций II отправил в Великую Армению в 338/339 гг. для борьбы против персов. Основные сведения о персидской экспедиции Констанция II сохранили армянские историки Мовсес Хоренаци и Павстос Бузанд, Констанций провел эту экспедицию с целью освободить территорию Великой Армении от персов и вернуть 
ей государственную независимость. Мовсес Хоренаци и Павстос Бузанд сообщают, что Констанций направил в Армению дружины нахараров - представителей армянской родовой знати, союзной римлянам, а собственно римские регулярные силы, собранные в Малой Азии (Галатии), перевел в Месопотамию и Атропатену (юг современного Азербайджана и Иранский Азербайджан). Но автор полагает, что римские войска прибыли и на территорию Армении, они приняли активное участие в боевых действиях с персами и именно благодаря римской военной помощи армянским нахарарам удалось изгнать персов с территории своего государства. В этой связи автор ставит вопрос о том, какие войсковые подразделения прибыли на римский Ближний Восток (в Месопотамию) из Малой Азии и как военная экспедиция Констанция II в Армению повлияла на дальнейшее развитие римско-персидского фронта и его системы обороны. На основании ряда эпиграфических документов (надписи из Месопотамии и Арабии) автор приходит к выводу, что в 338/339 гг. Констанций II перевел на Ближний Восток войсковые подразделения, ранее входившие в состав экспедиционной армии Фракии и размещавшиеся в этом регионе, поскольку все рассмотренные надписи упоминают воинов с фракийскими именами, что выдает их фракийское происхождение.

Ключевые слова: Констанций II, Фракия, экспедиционная армия, надписи, Ближний Восток, Великая Армения.

Цитирование. Мехамадиев Е. А. Армянская экспедиция императора Констанция II в 338/339 годах и войсковые подразделения экспедиционной армии Фракии на Ближнем Востоке: к вопросу о позднеримской военной организации в середине IV века // Вестник Волгоградского государственного университета. Серия 4, История. Регионоведение. Международные отношения. - 2017. - Т. 22, № 5. - C. 288-299. - DOI: https://doi. org/10.15688/jvolsu4.2017.5.26

Два армянских историка - Павстос Бузанд и Мовсес Хоренаци, первый из которых жил в V в [20, p. 1610, sv. P'awstos Buzand], a второй - определенно в VIII в. (как в свое время доказали К. Туманофф и Р. Томсон, [18, p. 49, 51-53, 59-60; 31, p. 471, 476; 32, p. 330334]), сохранили в своих трудах ряд ценных данных о римско-армянских взаимоотношениях в середине IV в., и в том числе - о военной экспедиции, которую император Констанций II, сын Константина I Великого, правивший в восточных провинциях империи (нижний Дунай, Малая Азия, Ближний Восток и Египет) в 337361 гг., совершил в Великую Армению (независимое царство, управляемое династией Аршакидов) с целью освободить ее территорию от персов и вернуть ей государственную независимость. Военно-политический контекст сведений обоих историков заключается в том, что в 338/339 гг. персидский принц Нарсей (тогда, как известно, царем Персии был Шапур II, правивший с 309 по 379 гг.) вторгся в земли Великой Армении, захватил и увел в плен нового царя Тирана (формально принял власть от своего отца, Хосрова III, в 338 г., сам же Хосров III правил с 330 по 338 г., соответственно, Хосров III был прямым наследником и преемником царя Трдата III Великого, который, как известно, крестил Армению ${ }^{1}$ ) и его семью, включая и наследника престола, Аршака, будущего Аршака II. В ответ армянская знать обратилась с просьбой о помощи к Констанцию II, римский император собрал армию и разгромил персов в сражении, развернувшемся на территории Армении. В итоге Тиран и Аршак вернулись в Армению, но поскольку во время персидского плена Тиран был ослеплен, он отказался от царской власти в пользу Аршака ${ }^{2}$.

В целом военный поход Констанция в Армению в 338/339 гг. вызывает неоднозначные трактовки исследователей - П. Питерс и В. Портманн полагали, что победа Констанция над персидским принцем Нарсеем, который, кстати, был убит в ходе битвы, а его гарем захвачен в плен, представляет собой вымышленную историю, такой битвы в реальности просто не было, и римские, и армянские историки перенесли на события 338/339 гг. победу одного из правителей эпохи Тетрархии (284305 гг.), Цезаря Максимина Галерия, над персидским царем Нарсеем, которая была одержана в 298 г. По мнению обоих исследователей, тем самым в римской и армянской историографии произошло удвоение битвы, один и тот же сюжет рассказали два раза, с одним только отличием - при изложении событий 338/ 339 гг. персидский царь Нарсей причудливым образом превратился в персидского принца Нарсея [21, p. 23, 43, 45; 23, S. 18].

Тем не менее, В. Портманн и П. Питерс подробно рассматривали сведения только од- 
ного римского историка - Феста, жившего в IV в., но Фест в своем «Бревиарии» четко упоминает, что «в (битве) же при Наразаренсе, где был убит Нарсей, мы (то есть римляне. E. M.) вышли победителями» (Narasarensi autem, ubi Narseus occiditur, superiores discessimus [11, p. 34, 27.2]), и у нас нет оснований сомневаться в достоверности сведений Феста, который обстоятельно и подробно перечислил, сколько всего сражений Констанций провел против персов в общий период с 338/ 339 по 350 год. Тем не менее подробное описание битвы дают именно армянские историки, поэтому мы не видим каких-либо серьезных причин подвергать сомнению и сведения армянской историографии.

Вместе с тем, «Хронография» византийского монаха и хрониста Феофана содержит интересный пассаж, к которому, как мы полагаем, следует обратиться для уточнения некоторых деталей экспедиции Констанция в 338/339 гг.

Под 322/323 гг. (5815 г. от сотворения мира) Феофан помещает небольшую запись, согласно которой «Нарсес, сын царя персов, напал на Месопотамию и захватил город Амиду. В этом году цезарь Констанций, сын Константина, выступил в военный поход, нанес удар и по прошествии небольшого времени одержал такую победу в битве, что убил са-

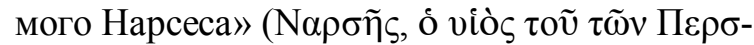

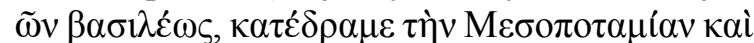

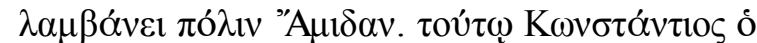

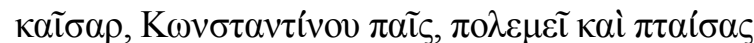

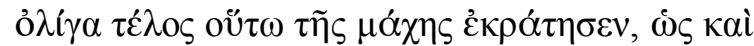

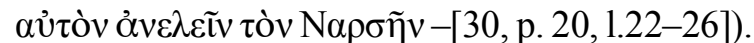

Вслед за Й. Марквартом В. Портманн датировал поход Нарсеса (= Нарсея) 335 г., поскольку именно в этом году Констанций впервые разместился на востоке империи, в Антиохии [23, S. 16]. Х. Арсе, оценивая пассаж Феофана, пришел к выводу, что Констанций разгромил персидского принца Нарсея, которого исследователь все же идентифицирует с братом, а не сыном царя Шапура II, именно в 335 г., и в награду за эту победу Констанций получил почетный титул Persicus Maximus [1, p. 247-248].

Но у нас возникают серьезные сомнения в правильности подобных трактовок, поскольку другое сообщение того же Феофана позволяет датировать битву с Нарсеем более поздним периодом, 338/339 гг., в то время как титул Persicus Maximus, с которым Констанций упоминается в надписи из крепости Троезмис (Troesmis, именно на нее ссылается $\mathrm{X}$. Арсе для подтверждения своих выводов), на наш взгляд, отражал именно кампанию 338/ 339 гг., а не 335 года. Под 336/337 гг. (5829 г. от сотворения мира) Феофан помещает запись о том, что «Сабор (то есть Шапур II. - E. M.), царь персов, напал на Месопотамию и осадил Нисибин, он размещался у (города) 63 дня, но, не сумев одолеть (город) и захватить его, он

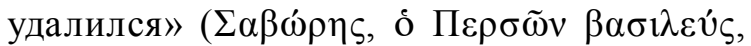
$\dot{\varepsilon} \pi \tilde{\eta} \lambda \theta \varepsilon \tau \tilde{\eta}$ M

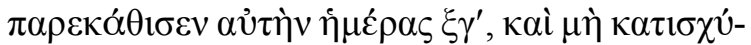

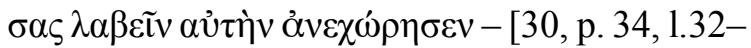
33 - p. 35, 1.1]. Сам В. Портманн датирует сообщение Феофана 337 или 338 гг. [23, S. 10], мы же полагаем, что в 338 г. персы вторглись в пределы империи в двух направлениях - сам царь Шапур II осадил Нисибис в Месопотамии, в то время как принц Нарсей захватил Амиду и затем направился в Великую Армению, где он отстранил от власти законного царя Тирана.

Соответственно, на наш взгляд, именно победа над Нарсеем дала Констанцию титул Persicus Maximus, если верить надписи, на которую ссылается Х. Арсе (опубликована в каталогах [14, p. 162-163, no. $724=22$, p. 251, nо. 238]). Тем не менее позволим себе заметить, что эта надпись упоминает всех трех братьев-соправителей, Констанция II, Константа и Константина II, но не упоминает их отца, императора Константина I Великого (Imp [pp(eratores) Caesss(ares)] / Fl(avius) Cl(audius) Constantinus Al[amann(icus) max(imus) Germ(anicus) max(imus) et] / Fl(avius) Iul(ius) Constantius Sarm(aticus) [Per]si[cu]s [max(imus) et] / [Fl(avius)] Iul(ius) Constans Sarm(aticus) Pii Felices Augg $<g>$ (usti) - «Императоры Цезари Флавий Клавдий Константин, великий аламаннский, великий германский, и Флавий Юлий Констанций, сарматский, великий персидский, и Флавий Юлий Констант, сарматский - благочестивые, счастливые Августы»), что позволяет датировать документ 337-340 гг., то есть периодом после смерти Константина I, но до смерти Константина II, убитого в ходе гражданской войны с Константом. 
Мы полагаем, что надпись была воздвигнута уже после того, как Констанций II совершил военный поход в Великую Армению против персов, то есть после 338/339 гг., эпиграфические и законодательные материалы, рассмотренные В. Рисом и Б. Блекманном, позволяют заключить, что в феврале 340 г. император Константин II, правивший в Галлии, еще не вступил в конфликт с Константом, который тогда находился в балкано-дунайских провинциях (в Дакии Речной), в то время как к апрелю 340 г. вооруженный конфликт уже завершился и Константин II был убит, а победитель Констант разместился в северной Италии, в Аквилее, вблизи которой, собственно, и произошла битва между двумя Августами [4, S. 231, 247; 24, S. 282-283].

Следовательно, надпись из крепости Троезмис. которая прославляет Константина II как живого Августа, определенно была составлена в 339/340 гг., вплоть до апреля 340 г., поэтому мы не можем приписать титул Persicus Maximus, с которым Констанций II упоминается в надписи, периоду 334/335 гг., мы полагаем, что Констанций II присвоил себе этот титул как раз в честь своей победы над персами в 338/339 гг.

Как детально установил Р. Барджесс, еще в конце июля 337 г., то есть уже через несколько месяцев после смерти Константина, Констанций провел на дунайской границе успешную кампанию против сарматов, по результатам которой он присвоил себе титул Sarmaticus Maximus [5, p. 41], опять же, согласно хронологии Р. Барджесса, в июне 337 г. Шапур II приступил к осаде Нисибиса в Месопотамии, но Констанций смог покинуть Константинополь и вернуться в Антиохию (как известно, он находился в Константинополе в связи с церемонией похорон своего отца) только в сентябре 337 г., соответственно, после прибытия в Антиохию Констанций II стал готовить контрнаступление, ответный удар против персов [5, p. 41-42].

Как мы полагаем, в 338/339 гг. Констанций нанес решительный удар по персам в Месопотамии, которые все еще контролировали Амиду, и затем вторгся в Великую Армению, где он нанес поражение войскам Нарсея и заставил персов оставить армянские земли. Поэтому мы считаем необходимым более подробно рассмотреть сведения армянских историков, упомянутых ранее (Павстос Бузанд и Мовсес Хоренаци), с целью выявить, какой была организационная структура той армии, которую Констанций II направил в Великую Армению против персов.

По словам Мовсеса, армия, отправленная Констанцием, состояла из двух войсковых группировок, первая, южная, находилась под командованием некоего Маначихра (судя по имени - армянского нахарара, представителя армянской родовой знати), эта группировка включала в себя и войска, навербованные в Киликии. Подразделения Маначихра прибыли в «земли Ассирии и Месопотамии», другая же группировка, восточная, под командованием Вахана (также армянский нахарар, союзный римлянам), включала в себя войска из Галатии - она отправилась «в земли Азербайджана (Атропатены, Адурбадагана, юг современного Азербайджана и территория Иранского Азербайджана. - E. M.), чтобы защитить их от персидского царя» (Manachichr with the southern army and that of Cilicia to the regions of Assyria and Mesopotamia; and Vahan... with the eastern force and the army of Galatia he sent to the regions of Azerbaijan to keep them secure from the Persian king $[18 \text {, p. } 259 \text {, III.6 }]^{3}$ ). Павстос Бузанд утверждает, что Констанций разместил основную базу (ставку, штаб-квартиру) своих войск в городе Сатала в Малой Армении (He left his own army around the sity of Satai - «он оставил свою собственную армию возле города Сатал») и назначил «командующими двух мудрых мужей из армянской армии» (and personally selected two leading wise men from the Armenian army [29, p. 98, III. 21]) ${ }^{4}$.

Тот же Павстос передает и другую важную деталь - незадолго до начала экспедиции нахарары, союзные римлянам, «взяли каждый свою дружину и отправились в изгнание в землю греков, и они принесли печальные новости нахарарам императорского войска, составленного из многочисленных отрядов» (took each his own household and fled into exile to the region of the Greeks, and they brought the sad news to the nayarars of the emperor's host [composed of] multiple contingents $\left[29\right.$, p. 98, III.21]) ${ }^{5}$.

Из цитированных пассажей на первый взгляд следует, что основная тяжесть боевых 


\section{ВИЗАНТИЯ И ВОЙНА}

действий в Великой Армении легла на плечи собственно армянских нахараров, которые сформировали из населения своих территорий войсковые соединения (дружины), вместе с этими дружинами они прибыли ко двору Констанция II. Дружины армянских нахараров, бежавших в пределы Римской империи, составили главную ударную силу, которая и была направлена в Армению, Констанций назначил двух командующих над этими дружинами непосредственно из числа армянской знати. В то же время римская армия, представленная войсковыми контингентами из Киликии и Галатии, разместилась в Месопотамии и Атропатене, прикрывая армянских нахараров с юга и северо-востока, тем не менее, мы полагаем, что в этой военной кампании римские подразделения не ограничились ролью только стороннего наблюдателя, они вошли на территорию Великой Армении и приняли активное участие в боевых действиях против персов.

Судя по всему, определенные войсковые контингенты римской армии прибыли в Армению для помощи и поддержки дружинам нахараров - трудно поверить, что непрофессиональные дружины нахараров, представлявшие собой, по сути, народное ополчение, обладали такими ресурсами и боевым опытом, чтобы своими силами эффективно противостоять персам и даже выбить их с территории Армении, подчеркнем, что проримская группировка армянской знати, отправившая Констанцию II письмо с просьбой о помощи, так и не смогла оказать сопротивление персам, ее собственных сил для этого было явно недостаточно ${ }^{6}$.

Сведения армянских авторов позволяют проследить перемещение римских армий и в другие регионы - на наш взгляд, Месопотамия, наравне с Арменией испытавшая всю тяжесть персидского вторжения, получила новые римские войсковые соединения из Малой Азии, а именно - из Галатии, как утверждает Мовсес Хоренаци точнее, из того региона, который армянский историк называет Галатией - дело в том, что еще в начале 337 г., в связи с подготовкой к предстоящей кампании против персов, император Константин I Великий перевел в Вифинию, соседнюю с Галатией провинцию, множество подразде- лений своей полевой (экспедиционной) армии comitatenses $^{7}$. Не исключено, что Мовсес Хоренаци, плохо осведомленный о римском административно-территориальном делении, просто перепутал Галатию с Вифинией, откуда, как мы полагаем, Месопотамия как раз и получила пополнение для своих пограничных гарнизонов.

Другой вопрос, что сами подразделения, дислоцировавшиеся зимой - весной 337 г. в Вифинии, были переведены туда из Фракии, где ранее размещалась полевая (экспедиционная) армия Константина I. Дело в том, что, как известно, еще в 324 г. Константин одержал полную и окончательную победу над своим последним внутриполитическим врагом императором Лицинием, который правил как раз в восточных и балкано-дунайских провинциях, боевые действия развернулись во Фракии и в Вифинии, где размещались основные силы Лициния, соответственно, после разгрома Лициния Константин перевел во Фракию свою победоносную экспедиционную армию, которой он присвоил почетное наименование (и одновременно официальный войсковой ранг) comitatenses в 325 году ${ }^{8}$.

Следовательно, если войсковые подразделения, переведенные в Великую Армению и Месопотамию в 338/339 гг., ранее размещались во Фракии (до зимы - весны 337 г.), а затем временно переместились в Вифинию, откуда они и направились на Ближний Восток, возникает закономерный вопрос - какие же подразделения в итоге прибыли в Армению и Месопотамию, какие военные отряды пополнили своими силами гарнизоны римского Ближнего Востока и как этот процесс изменил организационную структуру ближневосточного фронта в 340-х - начале 350-х гг.? Мы полагаем, что ответ на этот вопрос могут дать эпиграфические свидетельства из Месопотамии и провинции Арабия, располагавшейся, как известно, к югу от Месопотамии и Сирии. В сопоставлении с данными лингвистики и ономастики эти эпиграфические свидетельства проливают свет на вопрос об этническом происхождении воинов некоторых позднеримских подразделений, присутствие которых в Месопотамии и Арабии зафиксировано как раз благодаря надписям (надгробным эпитафиям), в свою очередь, этническое происхож- 
дение воинов даст возможность проследить, в каких регионах они были зачислены в армию и, соответственно, из каких регионов прибыли те войсковые части, в которых эти воины несли свою службу.

Первая надпись происходит из знаменитого города Зевгма в верховьях Евфрата (современный город Биреджик на юго-востоке Турции, ближе к турецко-сирийской границе [7, p. 278]), в 1977 г. М.П. Шпайдель предложил новое, улучшенное и исправленное, чтение этой надписи, версия М.П. Шпайделя была переиздана в каталоге AÉ 1977, цитируем текст по этому изданию [28, p. 239, no. 818]. Надпись упоминает войсковое подразделение Aureliaci:

Aur(elius) Benedictus / nat(us) pro(vincia) Cappa(docia) Ma[z(acae)] / T(h)ermas Basilicas su/ pervix(it) an(nos) X et amb(ulavit) in / sc(h)o(lam) $\mathrm{m}$ (enses) II deinde fato / suo sup(eratus) viat(or) iter $\mathrm{qu}[\mathrm{i}]$ / carpes res(ta) et relege miser(ere)/ Benedicto me(o) et ref[ir]ma / me Fla(vius) Uccaius cent(enarius) de Aureliacos / pos(uit) titulum filio suo bene merito

«Аврелий Бенедикт, рожден в провинции Каппадокия, (в городе) Мазака, у Царских Терм, прожил 10 лет, он ходил в школу 2 месяца, а затем погиб по воле своей судьбы; путник, который отправится по (этой) дороге - оставайся в живых, вновь посети (это место) и пожалей моего Бенедикта и вновь поддержи меня. Флавий Уккай, центенарий из (отряда) Аврелиаков, поставил памятник своему сыну, который достойно заслужил (этот памятник)»

М.П. Шпайдель идентифицировал отряд Aureliaci с вексилляцией equites scutarii Aureliaci, которая упоминается в Notitia Dignitatum, pars Occidentis, в главе по полевым войскам Британии [19, р. 142, VII.201]по мнению М.П. Шпайделя, Флавий Уккай был галло-римлянином, его имя говорит о кельтском происхождении, само же подразделение Aureliaci изначально размещалось в городе Aurelianenses (современный Орлеан) в Галлии, в честь которого подразделение получило свое название, а затем, после разгрома армии Магненция (351 г.), галльского узурпатора, с которым воевал император Констанций II, Aureliaci переместились в ближневосточные провинции, в верховья Евфрата, где их фиксирует цитированная выше надпись. Позже, в конце IV в., отряд Aureliaci вернулся на Запад, в Британию, где он полу- чил ранг вексилляции comitatenses и вошел в состав местной полевой (экспедиционной) армии [26, р. 272].

В 2014 г. Д. Дана предложил небольшую, но важную корректировку в чтении М.П. Шпайделя - по его мнению, имя офицеpa, служившего в вексилляции Aureliaci, следует читать как Flavius Liccaius - Флавий Ликкай, это имя, как полагает Д. Дана, отражает иллирийское (балкано-дунайское) происхождение офицера, Флавий Ликкай был уроженцем Паннонии или сопредельных провинций и там же он был зачислен в свой военный отряд [10, p. 193-194]. В целом Д. Дана, как и М.П. Шпайдель, склоняется к выводу, что вексилляция Aureliaci переместилась на Ближний Восток после победы над Магненцием, тем не менее, мы полагаем, что более вероятна другая трактовка - отряд (или вексилляция, как было бы правильней назвать подобное подразделение) Aureliaci был навербован Константином из жителей Орлеана еще в тот период, когда Константин дислоцировался в Галлии, то есть в 306-316 гг. (как известно, в 316 г. он переместил свою резиденцию в Сирмий на среднем Дунае для противостояния с Лицинием), соответственно, вместе с Константином вексилляция Aureliaci переместилась в балкано-дунайские провинции, на средний Дунай, где она первоначально разместилась в 316 г.

Когда же в 324 г. Константин одержал вторую, на этот раз - окончательную победу над Лицинием, и под власть императора-победителя перешла Фракия, он перевел туда свою экспедиционную армию, и в том числе вексилляцию Aureliaci, которая входила в состав этой армии. Очевидно, позже вексилляция Aureliaci вошла в состав того войскового экспедиционного корпуса, который Константин I взял с собой и перевел в Вифинию весной 337 г. для дальнейшей отправки уже на персидский фронт, в связи с этим напомним, что Флавий Ликкай носил родовое имя императора Константина I - Flavius, это имя стало общераспространенным и даже обязательным для военных и гражданских чиновников после 324 г., когда Константин установил свое единовластие во всей империи ${ }^{9}$. Пример с именем подсказывает, что, скорее всего, Флавий Ликкай поступил на службу или 


\section{ВИЗАНТИЯ И ВОЙНА}

в период единовластия Константина, то есть в 324-337 гг., или в эпоху правления его сыновей, и в том числе - Констанция II, который тоже носил родовое имя своего отца.

В свою очередь, когда власть над восточными провинциями империи получил Констанций II, он отправил многие соединения этого экспедиционного корпуса, и в том числе вексилляцию Aureliaci, на Ближний Восток, в Месопотамию, и на наш взгляд, перемещение из Малой Азии в Месопотамию состоялось как раз в 338/339 гг. в связи с персидской кампанией Констанция II на территории Великой Армении. Соответственно, совершенно неудивительно, что эпитафия из Месопотамии фиксирует пребывание в этой провинции воина балкано-дунайского (иллирийского) происхождения - мы не исключаем, что Флавий Ликкай вполне мог быть фракийцем по происхождению, то есть он принадлежал к местному населению Фракии и был зачислен в армию как раз в этой провинции. На наш взгляд, в тот период, когда вексилляция Aureliaci дислоцировалась во Фракии, то есть в 324-337 гг., она в значительной мере была пополнена рекрутами из этой провинции, к которым можно причислить и Флавия Ликкая.

Мы полагаем, что эпитафия, воздвигнутая в память о сыне Флавия Ликкая, в свою очередь, подтверждает, что Констанций II действительно перевел из Малой Азии определенную группу войсковых подразделений, которые входили в состав экспедиционной армии Фракии и до 337 г. размещались в нижнедунайских регионах. Тем не менее, судя по местонахождению самой эпитафии, гарнизон вексилляции Aureliaci размещался в верховьях Евфрата (в городе Зевгма), то есть в Месопотамии, текст надписи дает основание заключить, что центенарий Флавий Ликкай, служивший в вексилляции, квартировался вместе со своими сослуживцами в Зевгме, в то время как его семья находилась в Каппадокии, возможно, туда же должен был вернуться и сам Флавий после завершения своей службы.

Еще один пример перевода балкано-дунайских экспедиционных соединений на Ближний Восток - эпитафия из Бостры (Сирия, в римский период - провинция Арабия), опубликованная в каталоге IGLSyr, цитируем надпись по этому изданию: [15, p. 230, no. 9174]:
Coniux Biria/no, de numero / M(aurorum) Ill(yricianorum) Constan(tium)

«Супруга - Бириану, (воину) из отряда стойких иллирийских мавров»

Отряд Mauri Illyriciani Constantes, упоминаемый в надписи, можно идентифицировать с вексилляцией equites Mauri Illyriciani, которая, по данным Notitia Dignitatum, размещалась в провинции Арабия [19, р. 81, XXXVII.17], тем не менее, Д. Дана обращает внимание на еще один важный аспект надписи - по его мнению, имя офицера, которому посвящена эпитафия, следует читать как Bitianus, эта именная форма, как полагает Д. Дана, выдает фракийское происхождение офицера [10, p. 195].

С учетом наблюдений Д. Дана мы полагаем, что отряд Mauri Illyriciani Constantes разместился в Арабии в эпоху Констанция II, применительно к этому вопросу следует подчеркнуть - мы понимаем наименование Illyriciani именно как топоним, то есть название территории, где изначально был навербован отряд мавров. Этой территорией был Иллирик, то есть регионы, лежавшие по верхнему и нижнему течению Дуная, в основном в греко-латинских источниках Иллириком все же называли земли Паннонии, Далмации, верхней Мезии (современная Сербия) и Македонии ${ }^{10}$.

Из относительно новых исследований, посвященных подразделениям с наименованием Illyriciani, отметим работу А. Левина, который предположил, что вексилляции мавров, щитоносцев (scutarii), а также всадников promoti, наделенные этим наименованием и широко упоминающиеся в главах Notitia Dignitatum по ближневосточным провинциям, разместились на Ближнем Востоке в эпоху Диоклетиана (284-305 гг.) - он перевел из иллирийских (балкано-дунайских) провинций многие войсковые подразделения, присвоив им дополнительное наименование Illyriciani в честь территории, где они изначально были созданы или размещались ранее [16, р. 230, 232-233].

Но, как мы полагаем, та вексилляция, которая упоминается в надписи из Бостры, была переведена на Ближний Восток не в эпоху Диоклетиана, а в эпоху Констанция II - с учетом наблюдений Д. Дана мы можем признать, что в отряде мавров служили и выходцы из 
Фракии, воины, когда-то навербованные во Фракии, и среди этих воинов был Битиан. Наличие же в вексилляции Mauri Illyriciani Constantes офицера фракийского происхождения показывает, что эта вексилляция ранее, до своего перевода на ближневосточный фронт, находилась во Фракии, где она входила в состав армии comitatenses и пополнялась за счет местного фракийского населения.

И наконец, третий эпиграфический документ, своим содержанием затрагивающий нашу тему - латинская надпись, обнаруженная в селении Умм ель-Джималь на территории северной Иордании, надпись упоминает отряд щитоносцев (scutarii) и императора Констанция II (337-361 гг.), что однозначно позволяет датировать документ этим временем. Впоследствии в текст надписи вносились некоторые исправления, улучшающие или разъясняющие спорные моменты первого чтения, соответственно, цитируем документ по изданию: [17, p. 298, no. 197]:

$\mathrm{Fl}$ (avius) Lycianus $\mathrm{p}$ (rae)p(ositus) civi(tati)s Filip(p)op(o)/lis Th(r)acensia[n]e trib(unus) mil(iarensium?) / militante inter scutarios / d(omini) n(ostri) Constanti an(n)i(s) XXV s(emis)

«Флавий Лукиан, начальник (из) города Филиппополис во Фракии, трибун тысячных воинов, который отслужил в отряде щитоносцев нашего господина Констанци(я) 25 с половиной лет»

Первоиздатель документа, Дж.М. Рейнольдс, пришел к выводу, что Флавий Лукиан служил в отряде щитоносцев с 349 по 361 г. $[9$, p. 66], тем не менее, мы не согласны с такой датировкой, поскольку по целому ряду критериев она противоречит хронологии правления императора Констанция II и его территориальному местонахождению в период до 350 г. Прежде всего, мы принимаем мнение издателей AÉ 1961, no. 197, что первоначально Флавий Лукиан служил в отряде (схоле) скутариев (щитоносцев) в составе императорской гвардии Констанция II, а затем получил командование над войсковым подразделением milites miliarenses, судя по всему, гарнизон этих воинов находился вблизи миллиария милевого столба на арабском участке границы (отсюда и название гарнизона). Но где размещались скутарии, о которых идет речь в надписи? Мы полагаем, что они дислоциро- вались не в Константинополе, где в мирное время находилась императорская гвардия (скутарии, как известно, были одной из дворцовых схол - войсковых подразделений императорской гвардии).

Если Флавий Лукиан первоначально служил в схоле скутариев императора Констанция II, это значит, что сама схола скутариев размещалась там же, где и Констанций, проблема же состоит в том, что еще в 335 г. Констанций II впервые разместился на востоке империи, в Антиохии [23, S. 16], соответственно, на наш взгляд, уже в тот период в Антиохию была переведена схола скутариев, которая сопровождала своего императора во всех его походах и территориальных перемещениях. Антиохия в Сирии служила резиденцией Констанция вплоть до 350 г., когда он отправился в Галлию воевать с узурпатором Магненцием, который захватил там власть, следовательно, мы можем предположить, что схола скутариев, где служил Флавий Лукиан, дислоцировалась именно в Антиохии, а это, в свою очередь, позволяет заключить, что Флавий Лукиан отслужил в корпусе скутариев с 335 по 360 гг. (25,5 лет).

Как видим, в отряд скутариев был зачислен воин Флавий Лукиан, родившийся во Фракии. Если же Флавий Лукиан был уроженцем Фракии, это значит, что Констанций II пополнил свою гвардию местными жителями Фракии, следовательно, он рассматривал эту провинцию как ценный источник рекрутирования не только в пограничные, но и в элитные дворцовые соединения - можно предположить, что к моменту своего зачисления в отряд (схолу) скутариев Флавий Лукиан уже отслужил несколько лет в пограничных гарнизонах Фракии, во всяком случае, к этому времени он должен был приобрести ценный опыт боевой службы в пограничной армии, поскольку, как правило, в императорскую гвардию зачисляли только опытных и проверенных воинов. Обратим внимание - в первых строках надписи Флавий Лукиан назван «начальником» (praepositus), очевидно, в начале своей карьеры, когда он еще находился во Фракии, Флавий Лукиан командовал каким-либо военным гарнизоном, войсковым подразделением, размещавшимся во Фракии, возможно, этот гарнизон квартировался непосредствен- 


\section{ВИЗАНТИЯ И ВОЙНА}

но в Филиппополе, защищая город на случай нападений внешних врагов (готов или других германских племен). Д. Дана пришел к выводу, что Флавий Лукиан завершил свою карьеру в должности трибуна другого подразделения, дислоцировавшегося в Арабии - IX вексилляции далматов, то есть IX отряда далматской конницы $[10, \text { p. 195 }]^{11}$, на наш взгляд, конечно же, не исключено, что Флавий Лукиан командовал IX вексилляцией далматов, но только уже после того, как он отслужил в должности трибуна тысячных («милевых») воинов.

Но если Флавий Лукиан был воином фракийского происхождения, это значит, что надпись из Умм ель-Джималь - третий пример перевода экспедиционных сил Фракии на Ближний Восток в период Констанция II, точнее, заметим, что применительно к этому случаю мы скорее можем говорить не о переводе войскового подразделения, ранее дислоцировавшегося во Фракии, но целой группы молодых рекрутов и опытных офицеров, которые первоначально либо просто были зачислены в армию на территории Фракии, либо проходили там пограничную службу. Как видим, Констанций II пополнил фракийскими рекрутами и более опытными кадрами свою гвардию, то есть элитные соединения, находившиеся в штаб-квартире (ставке, резиденции) Констанция, то есть в Антиохии. Очевидно, позже, после 360 г., Флавий Лукиан был переведен на должность трибуна милевых воинов в провинции Арабия, то есть он стал командующим одного из пограничных гарнизонов этой провинции.

Следовательно, три рассмотренные надписи свидетельствуют о пребывании воинов фракийского происхождения на территории римских ближневосточных провинций (Месопотамии и Арабии), при этом подчеркнем воины, упомянутые в надписях, служили в тех подразделениях, которые были созданы либо в период Тетрархии, то есть на рубеже IIIIV вв., либо в эпоху императора Константина I (306-337 гг.). Мы связываем присутствие этих воинов в регионах персидского фронта с той военной экспедицией, которую Констанций II провел против персов в Великой Армении в 338/339 гг., как видим, одна из надписей прямо упоминает императора Констанция II (селение Умм ель-Джималь, Иордания). На наш взгляд, три эти надписи не только дополнительно подтверждают достоверность сведений Мовсеса Хоренаци и Павстоса Бузанда, но и позволяют внести в их сведения некоторые уточнения, касающиеся территориальных перемещений войсковых подразделений - 1) мы действительно можем утверждать, что император Констанций II перевел из Малой Азии (как говорят армянские историки) римские войсковые группы, безусловно, они состояли из подразделений экспедиционной армии; 2) другой вопрос, что сами эти подразделения ранее, еще до своего кратковременного пребывания в Малой Азии, откуда они и последовали на Ближний Восток, дислоцировались во Фракии, где их численный состав в значительной мере был пополнен местным населением, именно поэтому надписи упоминают воинов, носивших фракийские имена и родившихся во Фракии (как в случае с офицером Флавием Лукианом, надпись из Умм ельДжималь).

Мы полагаем, что перевод в Сирию, Месопотамию и Арабию войсковых подразделений, ранее размещавшихся во Фракии и входивших в состав ее экспедиционной армии, значительно усилил оборону ближневосточного лимеса от персидских и арабских набегов, по сути, новые гарнизоны позволили закрепить римские позиции в Месопотамии, где велись основные боевые действия с персами, благодаря этим гарнизонам римляне удерживали Месопотамию под своей властью вплоть до 363 г., когда они были вынуждены уступить эту провинцию персам из-за поражения Юлиана Отступника во время его персидской кампании.

\section{ПРИМЕЧАНИЯ}

${ }^{1}$ О хронологии правления армянских царей после Трдата III Великого см.: [12, р. 85].

2 Придерживаемся хронологии событий, предложенной Н. Бейнсом: [2, p. 627-629].

${ }^{3}$ Цитируем текст по английскому переводу Р. Томсона: [18, p. 259].

${ }^{4}$ Цитируем текст по английскому переводу Н. Гарсоян: [29, р. 98].

${ }^{5}$ Цитируем текст по английскому переводу Н. Гарсоян: [29, р. 98].

${ }^{6}$ В этом смысле мы категорически не согласны с точкой зрения Р. Хьюсена, который высказы- 
вает идею, что война римлян с персами развернулась в 335 г., еще при императоре Константине I Великом, тогда, по мнению исследователя, римляне не только выбили персов с территории Армении, но и разместили там племянника Константина, Ганнибалиана, который временно занял вакантный царский трон и правил Арменией в качестве царя, но от имени римлян. После того, как Ганнибалиан был убит в ходе дворцового заговора в Константинополе (337 г.), армянские нахарары, поддерживавшие Рим, избрали царем Аршака (II). Далее, как отмечает Р. Хьюсен, уже через два года, в 337 г., произошло новое вторжение персов в Армению, в результате которого Аршак II был уведен в плен. В следующем, 338 г., новый римский император Констанций II решил затянувшийся «армянский» вопрос дипломатическими методами - ему удалось договориться с персами о возвращении изгнанного Аршака в Армению, Аршак полноценно взошел на царский трон и с того времени уже непрерывно управлял Арменией вплоть до 364/365 гг. См.: [13, p. 109-112, 122]. Подобная трактовка, на наш взгляд, лишена каких бы то ни было оснований, поскольку возникает закономерный вопрос - как Констанций II мог решить «армянский» вопрос в 338 г. мирным путем, без применения военной силы? Р. Хьюсен сам признает, что персидское вторжение в Армению все-таки состоялось, значит, если следовать логике Р. Хьюсена, во время переговоров персидские войска продолжали контролировать территорию Армении. Но с какой тогда целью персы пошли на уступки и вернули в Армению плененного ими же Аршака, что заставило их пойти на такой шаг? На наш взгляд, причиной такого поворота в политике персов была военная операция римлян в Армении, вторжение римских войск в земли Армении. Мы полагаем, что возвращение Аршака в Армению состоялось именно благодаря военному столкновению Рима с Персией и победе над персидскими войсками, а значит, военная экспедиция римлян против персов произошла только один раз, в 338/339 гг.

${ }^{7}$ О резиденции Константина в последние годы его жизни и перемещении войск в Никомедию см.: [6, p. 159-160].

${ }^{8}$ Более подробно об этапах и механизме формирования экспедиционной армии Константина см.: [3, p. 108; 8, p. 126-127].

9 Как показал Б. Селвей, имя Flavius постепенно заменило имя Aurelius, которое было распространено в эпоху Диоклетиана, этот процесс отражал смену правящих династий - вплоть до 316 г., когда Константин одержал первую победунад Лицинием, все гражданские и военные чиновники носили имена Aurelius или Valerius, но после победы Константина члены его семьи и чиновники придворной администрации взяли себе имя Flavius. Это имя говорило о принадлежности его носителя либо к семье императора, либо к слою знатных и высокопоставленных чиновников, тем самым имя Flavius подразумевало высокий социальный статус его носителя. См.: [25, p. 138-139].

10 «Классическую» и базовую трактовку наименований Illyriciani в позднеримском военном лексиконе см.: [3, p. 81].

11 М.П. Шпайдель предположил, что надпись упоминает именно IX вексилляцию далматов, то есть Флавий Лукиан, по мнению исследователя, сначала служил в гвардии Констанция II в качестве щитоносца (скутария), а затем занял должность трибуна IX вексилляции далматов - тем не менее, текст надписи не позволяет утверждать столь однозначно, каким подразделением командовал Флавий Лукиан на завершающем этапе своей карьеры, мы принимаем версию авторов-составителей АÉ 1961, no. 197, поскольку первые сведения о IX вексилляции далматов датируются только концом 360-х-началом 370-х гг. См.: [27, p. 718-719].

\section{СПИСОК ЛИТЕРАТУРЫ}

1. Arce, J. The Inscription of Troesmis (ILS 724) and the First Victories of Constantius II as Caesar / J. Arce // ZPE. - 1982. - Bd. 48. - P. 245-249.

2. Baynes, N. Rome and Armenia in the Fourth Century/ N. Baynes // EHR. - 1910. - Vol. 25, № 100. P. 625-643.

3. Berchem, D. van. L'armée de Dioclétien et la réforme constantinienne / D. van Berchem. - Paris : Paul Geuthner, 1952. $-130 \mathrm{p}$.

4. Bleckmann, B. Der Bürgerkrieg zwischen Constantin II. und Constans (340 n. Chr.) / B. Bleckmann // Historia. - 2003. - Bd. 52, Hft. 2. S. 225-250.

5. Burgess, R. The Summer of Blood: the "Great Massacre" of 337 and the Promotion of the Sons of Constantine / R. Burgess // DOP. - 2008. - Vol. 62. P. 5-51.

6. Burgess, R. W. AXYP $\Omega N$ or ПPOA $\Sigma T E I O N$ : the Location and Circumstances of Constantine's Death / R. W. Burgess // JThS (NS). - 1999. - Vol. 50, № 1. - P. 153-161.

7. Chapot, V. La frontière de l'Euphrate de Pompée à la conquête arabe / V. Chapot. - Paris : Albert Fontemoign, 1907. $-407 \mathrm{p}$.

8. Colombo, M. Constantinus rerum novator: dal comitatus dioclezianeo ai palatini di Valentiniano I / M. Colombo // Klio. - 2008. - Bd. 90. - P. 124-161.

9. Corbett, G. U. S. Investigations at "Julianos Church" at Umm-el-Jemal / G. U. S. Corbett, J. M. Reynolds // PBSR. - 1957. - Vol. 25. - P. 39-66. 
10. Dana, D. Notices épigraphiques et onomastiques I / D. Dana // ZPE. - 2014. - Bd. 188. P. 181-198.

11. Festus. Abrégé des hauts faits du peuple Romain / éd. et tr. par M.-P. Arnaud-Lindet. - Paris : Belles Lettres, 1994. $-81 \mathrm{p}$.

12. Garsoïan, N. The Aršakuni Dynasty (A.D. 12 [180?]-428)/ N. Garsoïan // The Armenian People from Ancient to Modern Times. Vol. I/ ed. R. G. Hovannisian. N. Y. : St. Martin's Press, 1997. - P. 63-94.

13. Hewsen, R. H. The Successors of Tiridates the Great: a Contribution to the History of Armenia in the Fourth Century / R. H. Hewsen // RÉArm. - 19781979. - Vol. 13. - P. 99-126.

14. Inscriptiones Latinae selectae. Vol. I / ed. H. Dessau. - Berolini : apud Weidmannos, 1892. -580 p.

15. Inscriptions grecques et latines de la Syrie. T. XIII. Fasc. 1. Bostra. № 9001-9472 / éd. par M. Sartre. - Paris : Libr. orientaliste Paul Geuthner, 1982. $-441 \mathrm{p}$.

16. Lewin, A. Limitanei and comitatenses in the Near East from Diocletian to Valens / A. Lewin // L'armée Romaine de Dioclétien à Valentinien I ${ }^{\mathrm{er}}$. Actes du Congrès de Lyon (12-14 Septembre 2002) rassemblés et édités par Y. Le Bohec et C. Wolff. Lyon : de Boccard, 2004. - P. 227-236.

17. Merlin, A. Périodiques / A. Merlin // L’Anée épigraphique. - 1962. - Anée 1961. - P. 253 - 327.

18. Moses Khorenats' $i$. History of the Armenians / transl. and comment. by R. W. Thomson.-Cambridge (Mass.) : Harvard Univ. Press, 1978. - 408 p.

19. Notitia Dignitatum accedunt Notitia Urbis Constantinopolitanae et Laterculi provinciarum / ed. O. Seeck. - Berolini : apud Weidmannos, 1876. 339 p.

20. ODB. Vol. III / ed. in chief A. P. Kazhdan ; execut. ed. A. M. Talbot. - Oxford : Oxford Univ. Press, 1991. - P. 1475-2232.

21. Peeters, P. L'intervention politique de Constance II dans la Grande Arménie, en 338 / P. Peeters // Bulletin de l'Académie royale de Belgique. Classe des Lettres et des Sciences morales et politique. 5 série. - 1931. - Vol. 17, № 1. - P. 10-47.

22. Popescu, E. Inscripţiile greceşti şi latine din sec. IV-XIII descoperite în România / E. Popescu. Bucharest: Ed. Acad. Rep. Social. Rom., 1976. - 438 p.

23. Portmann, W. Die 59. Rede des Libanios und das Datum der Schlacht von Singara / W. Portmann // BZ. - 1989. - Bd. 82, Hft. 1. - S. 1-18.

24. Rieß, W. Konstantin und seine Söhne in Aquileia/W. Rieß// ZPE. -2001.-Bd. 135. -S. 267-283.

25. Salway, B. What's in a Name? A Survey of Roman Onomastic Practice from c. 700 B.C. to A.D. 700 / B. Salway // JRS. - 1994. - Vol. 84. - P. 124-145.

26. Speidel, M. P. A Cavalry Regiment from Orléan at Zeugma on the Euphrates: The Equites Scutarii
Aureliaci / M. P. Speidel // ZPE. - 1977. - Bd. 27. P. 271-273.

27. Speidel, M. P. The Roman Army in Arabia / M.P. Speidel // ANRW. II. Bd. 8. - Berlin ; N.Y. : De Gruyter, 1977. - P. 687-730.

28. Syrie-Phénicie// L’Anée épigraphique / réd. par A. Chastagnol [et al.]. - 1981.-Anée 1977. -P. 239-242.

29. The Epic Histories Attributed to Pawstos Buzand (Buzandaran Patmutiwnk) / transl. and comment. by N.G. Garsoïan. - Cambridge (Mass.) : Harvard Univ. Press, 1989. - 665 p.

30. Theophanis Chronographia. Vol. I. Textum graecum continens / rec. C. de Boor. - Lipsiae : B.G. Teubneri, 1883. -503 p.

31. Toumanoff, C. On the Date of Pseudo-Moses of Chorene / C. Toumanoff // Handes Amsorya. 1961. - Vol. 75. - P. 467-476.

32. Toumanoff, C. Studies in Christian Caucasian History / C. Toumanoff. - Georgetown : Georgetown Univ. Press, 1963. -599 p.

\section{REFERENCES}

1. Arce J. The Inscription of Troesmis (ILS 724) and the First Victories of Constantius II as Caesar. ZPE, 1982, vol. 48, pp. 245-249.

2. Baynes N. Rome and Armenia in the Fourth Century. EHR, 1910, vol. 25, no. 100, pp. 625-643.

3. Berchem D. van. L'armée de Dioclétien et la réforme constantinienne. Paris, Paul Geuthner, 1952.130 p.

4. Bleckmann B. Der Bürgerkrieg zwischen Constantin II. und Constans (340 n. Chr.). Historia, 2003, vol. 52, no. 2, pp. 225-250.

5. Burgess R. The Summer of Blood: the "Great Massacre" of 337 and the Promotion of the Sons of Constantine. DOP, 2008, vol. 62, pp. 5-51.

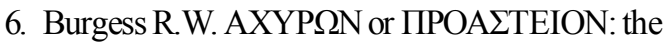
Location and Circumstances of Constantine's Death. JThS (NS), 1999, vol. 50, no. 1, pp. 153-161.

7. Chapot V. La frontière de l'Euphrate de Pompée à la conquête arabe. Paris, Albert Fontemoign, $1907.407 \mathrm{p}$.

8. Colombo M. Constantinus rerum novator: dal comitatus dioclezianeo ai palatini di Valentiniano I. Klio, 2008, vol. 90, pp. 124-161.

9. Corbett G.U.S., Reynolds J.M. Investigations at "Julianos Church" at Umm-el-Jemal. PBSR, 1957, vol. 25, pp. 39-66.

10. Dana D. Notices épigraphiques et onomastiques I. ZPE, 2014, vol. 188, pp. 181-198.

11. Arnaud-Lindet M.-P., ed. Festus. Abrégé des hauts faits du peuple Romain. Paris, Belles Lettres, $1994.81 \mathrm{p}$.

12. Garsoïan N. The Aršakuni Dynasty (A.D. 12[180?]-428). Hovannisian R.G., ed. The Armenian 
People from Ancient to Modern Times. Vol. I. N.Y., St. Martin's Press, 1997, pp. 63-94.

13. Hewsen R.H. The Successors of Tiridates the Great: a Contribution to the History of Armenia in the Fourth Century. RÉArm, 1978-1979, vol. 13, pp. 99-126.

14. Dessau H., ed. Inscriptiones Latinae selectae. Vol. I. Berolini, apud Weidmannos, $1892.580 \mathrm{p}$.

15. Sartre M., ed. Inscriptions grecques et latines de la Syrie. T. XIII. Fasc. 1. Bostra. N. 9001-9472. Paris, Libr. orientaliste Paul Geuthner, 1982. 441 p.

16. Lewin A. Limitanei and comitatenses in the Near East from Diocletian to Valens. L'armée Romaine de Dioclétien à Valentinien $I^{e r}$. Actes du Congrès de Lyon (12-14 Septembre 2002) rassemblés et édités par Y. Le Bohec et C. Wolff. Lyon, de Boccard, 2004, pp. 227-236.

17. Merlin A. Périodiques. $A E$, 1962, anée 1961, pp. 253-327.

18. Thomson R.W., ed. Moses Khorenats ' $i$. History of the Armenians. Cambridge (Mass.), Harvard Univ. Press, 1978. 408 p.

19. Seeck O., ed. Notitia Dignitatum accedunt Notitia Urbis Constantinopolitanae et Laterculi provinciarum. Berolini, apud Weidmannos, 1876.339 p.

20. Kazhdan A.P., Talbot A.M., eds. ODB. Vol. III. Oxford, Oxford Univ. Press, 1991, pp. 1475-2232.

21. Peeters P. L'intervention politique de Constance II dans la Grande Arménie, en 338. Bulletin de l'Académie royale de Belgique. Classe des Lettres et des Sciences morales et politique. $5^{e}$ série, 1931, vol. 17, no. 1, pp. 10-47.

22. Popescu E. Inscripțiile greceşti şi latine din sec. IV-XIII descoperite on România. Bucharest, Ed. Acad. Rep. Social. Rom., 1976. 438 p.

23. Portmann W. Die 59. Rede des Libanios und das Datum der Schlacht von Singara. BZ, 1989, vol. 82, no. 1, pp. 1-18.

24. Rieß W. Konstantin und seine Söhne in Aquileia. ZPE, 2001, vol. 135, pp. 267-283.
25. Salway B. What's in a Name? A Survey of Roman Onomastic Practice from c. 700 B.C. to A.D. 700. JRS, 1994, vol. 84, pp. 124-145.

26. Speidel M.P. A Cavalry Regiment from Orléan at Zeugma on the Euphrates: The Equites Scutarii Aureliaci. ZPE, 1977, vol. 27, pp. 271-273.

27. Speidel M.P. The Roman Army in Arabia. $A N R W$, II, Bd. 8. Berlin; N. Y., DeGruyter, 1977, pp. 687-730.

28. Syrie-Phénicie. Chastagnol A., ed. L'Anée épigraphique, 1981, anée 1977, pp. 239-242.

29. Garsoïan N.G., ed. The Epic Histories Attributed to Pawstos Buzand (Buzandaran Patmutiwnk). Cambridge (Mass.), Harvard Univ. Press, $1989.665 \mathrm{p}$.

30. Boor C. de, ed. Theophanis Chronographia. Vol. I. Textum graecum continens. Lipsiae, B.G. Teubneri, $1883.503 \mathrm{p}$.

31. ToumanoffC. On the Date of Pseudo-Moses of Chorene. Handes Amsorya, 1961, vol. 75, pp. 467-476.

32. Toumanoff C. Studies in Christian Caucasian History. Georgetown, Georgetown Univ. Press, 1963. $599 \mathrm{p}$.

\section{СПИСОК УСЛОВНЫХ СОКРАЩЕНИЙ}

AÉ - L'Anée épigraphique.

ANRW - Aufstieg und Niedergang der römischen Welt.

BZ-Byzantinische Zeitschrift.

EHR - The English Historical Review.

DOP - Dumbarton Oaks Papers.

JThS - The Journal of Theological Studies.

JRS - The Journal of Roman Studies.

IGLSyr-Inscriptions grecques et latines de la Syrie.

ODB - Oxford Dictionary of Byzantium.

PBSR - Papers of the British School at Rome.

RÉArm - Revue des Études Arméniennes.

ZPE - Zeitschrift für Papyrologie und Epigraphik.

\section{Information about the Author}

Evgeniy A. Mekhamadiev, Candidate of Sciences (History), Senior Lecturer, Department of Medieval History, Saint Petersburg State University, Universitetskaya naberezhnaya, 7-9, 199034 Saint Petersburg, e.mehamadiev@spbu.ru, https://orcid.org/0000-0003-1823-4588

\section{Информация об авторе}

Евгений Александрович Мехамадиев, кандидат исторических наук, старший преподаватель кафедры истории Средних веков, Санкт-Петербургский государственный университет, Университетская набережная, 7-9, 199034 г. Санкт-Петербург, Российская Федерация, e.mehamadiev@spbu.ru, https://orcid.org/0000-0003-1823-4588 